\title{
Self-acceptance of high school students in Indonesia
}

\author{
Refnadi Refnadi ${ }^{1}$, Marjohan Marjohan ${ }^{1}$, Yarmis Yarmis ${ }^{1}$ \\ ${ }^{1}$ Pasca Sarjana Bimbingan dan Konseling, Universitas Negeri Padang, Indonesia
}

\begin{tabular}{l} 
Article Info \\
\hline Article history: \\
Received Jan $25^{\text {th }}, 2021$ \\
Revised Feb $5^{\text {th }}, 2021$ \\
Accepted Feb $15^{\text {th }}, 2021$ \\
\hline
\end{tabular}

\section{Keyword:}

Self-Acceptance

High School

Student

Rasch Analysis

\begin{abstract}
Tujuan penelitian ini adalah mendeskripsikan kondisi penerimaan diri siswa Sekolah Menengah Atas (SMA) di Indonesia berdasarkan gender, etnis, jumlah akun media social, dan jumlah pertemanan di sosial media. Jenis penelitian deskriptif dengan sampel penelitian berjumlah 251 siswa yang terdiri dari $31.5 \%$ laki-laki dan $68.5 \%$ perempuan siswa SMA yang ada di Indonesia. Data dalam penelitian ini berupa data politomi 5-point Likert scale yang dikumpulkan menggunakan instrument self acceptance yang diadopsi dari (Maryam \& Ifdil, 2019) yang disesuaikan dengan karakteristik data dan subjek peneltian, instrumen terdiri dari 32 item yang disebarkan secara online. Data penelitian dianalisis mengunakan model Rasch dengan menggunakan variable maps, subtotal specification, and differential item functional. Hasil temuan menunjukkan $18.3 \%$ berada pada kondisi penerimaan diri tinggi, $36.6 \%$ berada pada kondisi penerimaan diri sedang, dan $45.4 \%$ berada pada kondisi penerimaan diri rendah. Selain itu, siswa laki-laki (.58 logit) lebih tinggi penerimaan dirinya dibandingkan dengan perempuan (.51 logit.
\end{abstract}

C 2021 The Authors. Published by IICET.

This is an open access article under the CC BY-NC-SA license

(https://creativecommons.org/licenses/by-nc-sa/4.0

\section{Corresponding Author:}

Refnadi,

Pasca Sarjana Bimbingan dan Konseling, Universitas Negeri Padang, Indonesia

Email: refnadi@gmail.com

\section{Introduction}

Dunia telah memasuki era revolusi industri 4.0 ditandai dengan semakin berkembangnya teknologi digital (Adiansah, Setiawan, Kodaruddin, \& Wibowo, 2019). Perkembangan teknologi digital memberi dampak masif terhadap kehidupan manusia, salah satu perkembangan teknologi digital pada era ini adalah perkembangan internet of things (IoT) atau disebut "internet of all things" yang memungkinkan untuk menghubungkan hal fisik ke dunia virtual (Schwab, 2016). Lebih lanjut Schwab memaparkan bahwa miliaran perangkat di seluruh dunia seperti smarthphone, tablet, dan komputer terhubung ke internet, bahkan diperkirakan akan meningkat hingga lebih dari satu triliun. Kecanggihan yang tergintegrasi di dalam smartphone menciptakan budaya baru bagi sosial masyarakat, bahkan sudah menjadi style (gaya hidup), pencerminan diri, serta status sosial individu (Art, 2016).

Faktanya generasi milenial kini tidak bisa jauh dari teknologi, hal ini yang mendorong penerimaan diri remaja semakin rendah (Ilma \& Muslimin, 2020), 72\% dari 179 siswa memiliki tingkat penerimaan diri sedang dan 14\% siswa yang memiliki penerimaan diri rendah (Simanjuntak, 2013), 41\% dari 60 siswa yang memiliki penerimaan diri rendah (Yahya, 2013). Survei yang dilakukan ZAP Beauty Index tahun 2018 menunjukkan sebesar 35,9\% wanita dari generasi milenial dan 48,9\% remaja wanita dengan rentang usia 18-23 tahun yang tidak percaya diri dengan kondisi fisiknya (ZAP Clinic, 2018). Ketidakpuasan dengan tubuh sendiri mendorong seseorang untuk mendapatkan tubuh yang ideal dengan melakukan berbagai upaya (Suprapto, Sari, \& Nurcahyo, 2015). Kurangnya rasa percaya diri terhadap kondisi fisik membuat seseorang mudah 
terpengaruh dengan orang lain dan tidak dapat bertindak sesuai dengan keinginan sendiri (ZAP Clinic, 2018). Kondisi tersebut mengakibatkan pada penilaian diri yang negatif seperti menilai diri tidak menarik dan cenderung membandingkan bentuk tubuh yang mereka miliki dengan bentuk tubuh yang ideal (Ogden \& Evans, 1996). Hal ini didukung oleh (Wang, Moon, Kwon, Evans, \& Stefanone, 2010) mengungkapkan tampilan foto profil seseorang di FB berpengaruh signifikan terhadap kemauan untuk menjalin pertemanan dengan pemilik profil, karena dengan tampilan foto profil yang menarik dapat membuat daya tarik fisik, sehingga digunakan sebagai isyarat visual ketika memilih siapa yang akan ditemaninya. Selain itu, remaja laki-laki dan perempuan lebih berkeinginan untuk menjalin persahabatan dengan akun FB yang memiliki profil lawan jenis dengan foto yang menarik (Nadkarni \& Hofmann, 2012).

Walaupun perkembangan teknologi semakin meningkat, isu mengenai penerimaan diri remaja masih menjadi topik yang menarik untuk dibahas para peneliti kesehatan mental karena wanita dari generasi milenial masih tidak percaya diri dengan kondisi fisiknya, sehingga penelitian ini berfokus pada penerimaan diri siswa Sekolah Menengah Atas di Indonesia. Individu dapat dikatakan memiliki penerimaan diri yang tinggi, apabila dapat menerima segala sesuatu yang ada pada dirinya baik kelemahan maupun kelebihannya sehingga jika terjadi peristiwa yang tidak menyenangkan, mereka akan mampu berpikir secara logis tentang masalah yang telah terjadi tanpa menyebabkannya. perasaan bermusuhan, rendah diri, malu, dan tidak aman (Hurlock, 2011). Untuk itu individu dikatakan berhasil melewati tugas perkembangan, apabila sudah menerima kondisi fisik dan kualitas dirinya (Yusuf, 2006). Penelitian ini bertujuan untuk mendeskripsikan kondisi penerimaan diri siswa Sekolah Menengah Atas di Indonesia berdasarkan gender, etnis, jumlah akun media social, dan jumlah pertemanan di sosial media.

\section{Method}

Jenis penelitian deskriptif, Sampel penelitian berjumlah 251 orang siswa di SMA Pembangunan Laboratorium UNP. Adapun gambaran demografi responden terlihat pada tabel 1.

Tabel $1<$ Demografi Responden Penelitian>

\begin{tabular}{|c|c|c|c|c|c|c|}
\hline Kelas & Jurusan & $\begin{array}{c}\text { Jenis } \\
\text { Kelamin }\end{array}$ & Etnis & $\begin{array}{l}\text { Jumlah Akun } \\
\text { Sosial Media }\end{array}$ & Asal Domisili & $\begin{array}{c}\text { Jumlah } \\
\text { Pertemanan } \\
\text { Sosial } \\
\text { Media }\end{array}$ \\
\hline$X(1), n=50$ & $\begin{array}{l}\text { IPA (A), } \\
n=82\end{array}$ & $\begin{array}{l}\text { Laki-laki (L), } \\
\mathrm{n}=79\end{array}$ & $\begin{array}{l}\text { Jawa }(J), n= \\
12\end{array}$ & $\begin{array}{l}>3(\mathrm{~T}), \mathrm{n}= \\
86\end{array}$ & $\begin{array}{l}\text { Kota Besar (B), n } \\
=166\end{array}$ & $\begin{array}{l}<200(1), \mathrm{n} \\
=76\end{array}$ \\
\hline $\begin{array}{l}X I(2), n= \\
77\end{array}$ & $\begin{array}{l}\text { IPS (S), } \\
\mathrm{n}=124\end{array}$ & $\begin{array}{l}\text { Perempuan } \\
\text { (P), } n=172\end{array}$ & $\begin{array}{l}\text { Melayu (U), } \\
\mathrm{n}=10\end{array}$ & $3(S), n=59$ & $\begin{array}{l}\text { Kota } \\
\text { Kecil/kabupaten, } \\
\mathrm{n}=76\end{array}$ & $\begin{array}{l}<300(2), \mathrm{n} \\
=38\end{array}$ \\
\hline \multirow[t]{2}{*}{$\begin{array}{l}\text { XII (3), } n= \\
124\end{array}$} & $\begin{array}{l}\text { Bahasa } \\
(\mathrm{B}), \mathrm{n}= \\
45\end{array}$ & & $\begin{array}{l}\text { Minang }(M), \\
\mathrm{n}=220\end{array}$ & $2(\mathrm{R}), \mathrm{n}=64$ & Pedesaan, $\mathrm{n}=9$ & $\begin{array}{l}<400(3), \mathrm{n} \\
=25\end{array}$ \\
\hline & & & $\begin{array}{l}\text { Kerinci }(\mathrm{K}), \mathrm{n} \\
=6 \\
\text { Bugis }(\mathrm{B}), \mathrm{n}= \\
3\end{array}$ & $1(\mathrm{~N}), \mathrm{n}=42$ & & $\begin{array}{l}>500(4), n \\
=112\end{array}$ \\
\hline
\end{tabular}

\section{Procedures}

Para siswa diberi sebuah instrument self acceptance yang diberikan secara online. Setiap responden dapat memilih satu dari lima alternatif jawaban yang disediakan (selalu $=5$ sampai tidak pernah $=1$ ) dan 40 menit waktu yang diberikan untuk mengisi instrument tersebut.

\section{Measuring}

Penelitian ini menggunakan instrument self acceptance yang diadopsi dari (Maryam \& Ifdil, 2019) yang disesuaikan dengan karakteristik data dan subjek peneltian, instrumen terdiri dari 32 item yang disebarkan secara online. Instrument ini mengukur delapan indikator, yaitu: 1) menerima kekurangan, 2) mengakuikelebihan, 3) mencintai kehidupan yang dimiliki, 4) tidak membandingkan diri sendiri dengan orang lain, 5) melakukan sesuatu yang bermanfaat untuk orang lain, 6) optimis, 7) mampu mengatasi masalah akibat perlakuannya, dan 8) tidak menyalahkan orang lain. Lebih lanjut, instrumen menggunakan 5-point Likert scale dengan jumlah 32 item. Adapun hasil uji validasi instrument disampaikan pada tabel 2 berikut. 
Hasil uji validasi pada Tabel 2 menunjukkan bahwa reliabilitas instrument self acceptance berada pada tingkat yang sangat baik dengan nilai .99. Ini juga didukung oleh nilai indeks pemisahan yang dapat mengatur item menjadi 10 bagian, dari yang sangat tinggi sampai paling sangat rendah. Selanjutnya, pada estimasi unidimensional melalui Principal component analysis (PCA) mengidentifikasi nilai varians mentah dijelaskan dengan ukuran $41.6 \%$, hal ini berarti bahwa kondisi unidimensi instrumen telah tercapai ( $>40 \%$; Boone, Stever, \& Yale, 2014; Linacre, 2011) dan konstruk pada instrument sudah mewakili untuk mengukur kondisi penerimaan diri siswa.

Tabel $2<$ Hasil Uji Validasi Instrumen Self Acceptance>

\section{Estimation}

Values

Item Reliabilities

Person Reliabilities

Cronbach alpha (KR-20)

Separation index of Item

\section{Data Analysis}

Data penelitian dianalisis mengunakan model Rasch dengan menggunakan 3 analisis, yaitu: 1) pengujian kondisi self acceptance dengan menggunakan variable maps, 2) pengujian deskriptif dengan menggunakan subtotal specification, dan 3) pengujian persepsi berdasarkan demografi dengan menggunakan differential item functional (DIF; Bond \& Fox, 2015; Boone et al., 2014; Syahputra \& Erwinda, 2020).

\section{Results and Discussions}

Untuk mencapai tujuan penelitian ada 3 analisis, yaitu: 1) pengujian kondisi self acceptance dengan menggunakan variable maps, 2) pengujian deskriptif dengan menggunakan subtotal specification, dan 3) pengujian persepsi berdasarkan demografi dengan menggunakan differential item functional (DIF; Bond \& Fox, 2015; Boone et al., 2014; Syahputra \& Erwinda, 2020).

\section{Kondisi Penerimaan Diri Siswa di Sekolah Menengah Atas: Analisis variable maps}

Pada gambar 1 menunjukkan wright maps pada variable maps sebelah kiri menjelaskan kondisi penerimaan diri siswa dan wright maps sebelah kanan menjelaskan ability item-item self acceptance. Pada wright maps sebelah kiri menunjukkan perimaan diri siswa lebih tinggi daripada rata-rata kemampuan item mengungkap self acceptance, ditandai dengan nilai mean person lebih tinggi 0.56 logit daripada mean item. Artinya, siswa mudah menyetujui pernyataan-pernyataan pada instrument dan kondisi pernerimaan diri siswa berada pada tingkat sedang. Sementara wright maps sebelah kanan menunjukkan kualitas dari item-item penerimaan diri. Item P27 (-1.66 logit) menjadi paling mudah dijawab dengan benar oleh siswa karena pernyataan item tersebut sering dirasakan oleh seluruh siswa, adapaun bunyi pernyataan "Saya bersyukur atas apa yang Tuhan berikan".

Sedangkan item P23 (+1.04 logit) menjadi item yang paling sulit disetujui oleh siswa karena pernyataan item tersebut kurang dirasakan oleh seluruh siswa, adapun bunyi pernyataan "Saya tidak memperdulikan penilaian buruk dari orang lain terhadap diri saya". Namun, wright maps sebelah kiri menunjukkan ada 46 siswa yang mampu menyetujui item P23, artinya 46 siswa dengan persentase $18.3 \%$ berada pada kondisi penerimaan diri yang tinggi. Sementara, 91 siswa dengan persentase $36.6 \%$ berada pada kategori sedang dengan rentang logit $+1.15 \mathrm{~s} / \mathrm{d}+0.35$, dan 114 siswa dengan persentase $45.4 \%$ berada pada kategori rendah dengan rentang logit $+0.35 \mathrm{~s} / \mathrm{d}-0.89$. Selaras dengan (Simanjuntak, 2013) 72\% dari 179 siswa memiliki tingkat penerimaan diri sedang dan $14 \%$ siswa yang memiliki penerimaan diri rendah. 


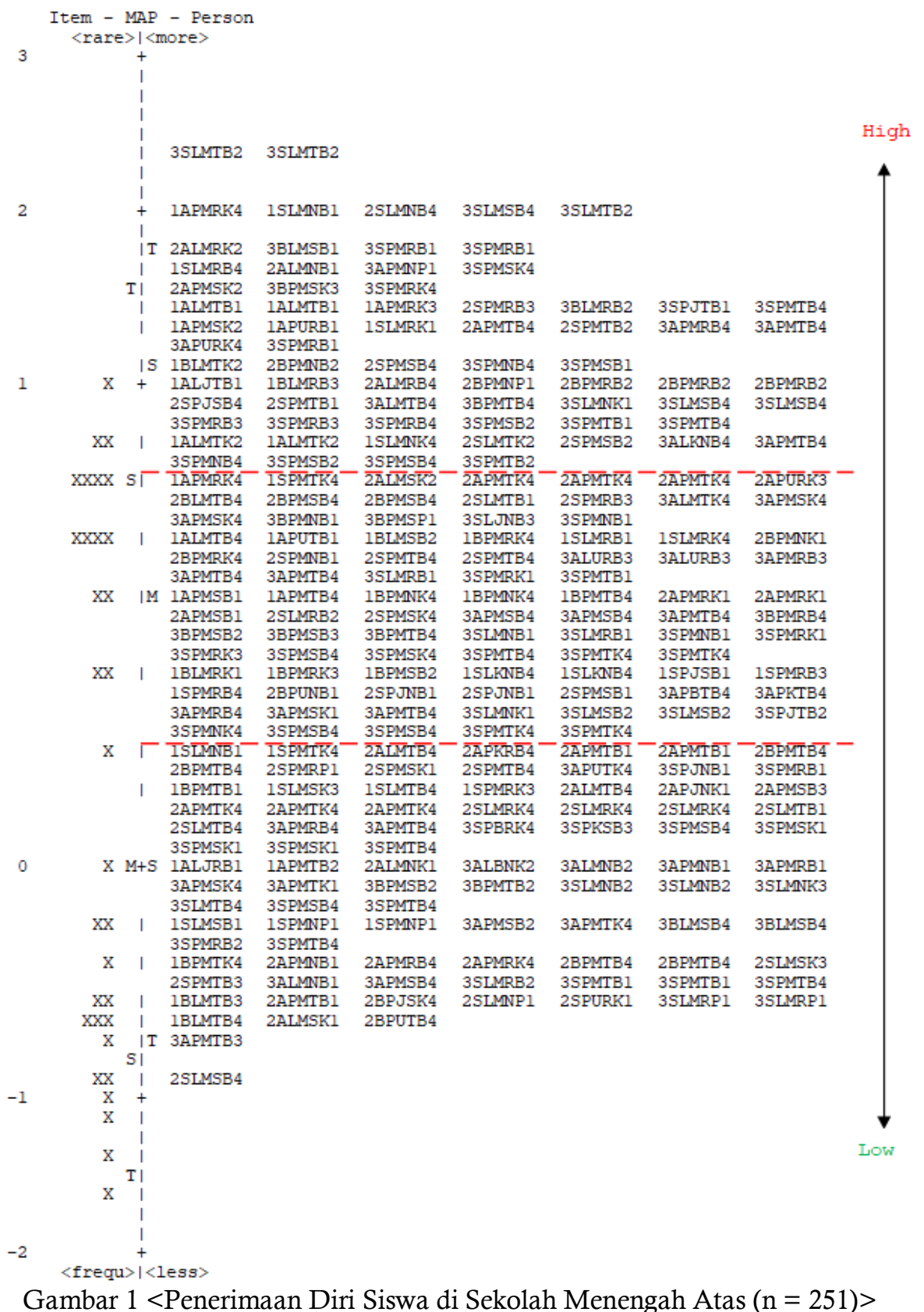

Kondisi Penerimaan diri Berdasarkan Demografi: Analisis subtotal specification

Tabel $3<$ Hasil Uji Deskriptif Penerimaan Diri Berdasarakan Jurusan>

\begin{tabular}{lccccccc}
\hline $\begin{array}{c}\text { Person } \\
\text { Count }\end{array}$ & $\begin{array}{c}\text { Mean } \\
\text { Measure }\end{array}$ & $\begin{array}{c}\text { S.E. } \\
\text { Mean }\end{array}$ & Median & $\begin{array}{c}\text { Model } \\
\text { Separation }\end{array}$ & $\begin{array}{c}\text { Model } \\
\text { Reliability }\end{array}$ & Code \\
\hline 251 & .53 & .04 & .49 & 2.77 & .88 & $*$ & \\
82 & .52 & .06 & .52 & 2.66 & .88 & $\mathrm{~A}$ & \\
45 & .49 & .08 & .49 & 2.57 & .87 & $\mathrm{~B}$ & \\
124 & .55 & .05 & .45 & 2.90 & .89 & $\mathrm{~S}$ & \\
\hline
\end{tabular}

Explanation:
A $\quad=$ IPA
$\mathrm{B} \quad=$ Bahasa
$\mathrm{S} \quad=\mathrm{IPS}$

Tabel 3 menunjukkan total siswa sebanyak 251 (IPA, $n=82$; IPS, $n=124$; dan Bahasa, $n=45$ ). Mean measure IPS (.55 logit) lebih besar dibandingkan jurusan lain, artinya jurusan IPS lebih memiliki penerimaan 
diri dibandingkan IPA maupun Bahasa. Berbeda dengan nilai S.E Mean bahwa jurusan Bahasa (.08) lebih besar daripada jurusan lain, artinya kesalahan atau penyimpangan lebih besar terjadi pada siswa jurusan Bahasa. Model reliability siswa jurusan IPS sedikit lebih tinggi dibandingkan jurusan lain, bila ditinjau dari kualitas jawaban yang diberikan seluruh siswa bagus.

Tabel 4 <Hasil Uji Deskriptif Penerimaan Diri Berdasarakan Jenis Kelamin>

\begin{tabular}{lcccccc}
\hline Person Count & Mean Measure & $\begin{array}{c}\text { S.E. } \\
\text { Mean }\end{array}$ & Median & Model Separation & Model Reliability & Code \\
\hline 251 & .53 & .04 & .49 & 2.77 & .88 & $*$ \\
79 & .58 & .08 & .52 & 3.39 & .92 & $\mathrm{~L}$ \\
172 & .51 & .04 & .49 & 2.39 & .85 & $\mathrm{P}$ \\
\hline
\end{tabular}

Explanation:

$$
\begin{array}{ll}
\mathrm{L} & =\text { Laki-laki } \\
\mathrm{P} & =\text { Perempuan }
\end{array}
$$

Tabel 4 menunjukkan siswa yang paling dominan mengisi instrumen penerimaan diri dari perempuan (n = 172). Namun, yang memberikan respon terbaik bukan dari perempuan, melainkan dari siswa laki-laki, terlihat dari nilai reliability sebesar .92 dibandingkan dengan nilai reliability perempuan. Sama halnya dengan nilai separation index (3.39) menunjukkan siswa laki-laki lebih tinggi dibandingkan perempuan, artinya respon siswa laki-laki dapat dibedakan menjadi 3 kelompok, yaitu: tinggi, sedang, dan rendah. Selaras dengan penelitian di Yogyakarta oleh (Ilma \& Muslimin, 2020) mengungkapkan penerimaan diri mahasiswa laki-laki lebih tinggi daripada perempuan. Berbeda dengan temuan studi lain dalam literatur yang sama bahwa tingkat penerimaan diri perempuan lebih tinggi daripada laki-laki (Negovan, Bagana, \& Dinca, 2011), dan hasil lain menemukan selama masa remaja tingkat penerimaan diri meningkat (Ceyhan \& Ceyhan, 2010). Selanjutnya, kondisi penerimaan diri berdasarkan etinis di Indonesia disampaikan pada tabel 5 berikut.

Tabel $5<$ Hasil Uji Deskriptif Penerimaan Diri Berdasarakan Etnis di Indonesia>

\begin{tabular}{lcccccc}
\hline \multicolumn{1}{r}{$\begin{array}{c}\text { Person } \\
\text { Count }\end{array}$} & $\begin{array}{c}\text { Mean } \\
\text { Measure }\end{array}$ & $\begin{array}{c}\text { S.E. } \\
\text { Mean }\end{array}$ & Median & $\begin{array}{c}\text { Model } \\
\text { Separation }\end{array}$ & $\begin{array}{c}\text { Model } \\
\text { Reliability }\end{array}$ & Code \\
251 & .53 & .04 & .49 & 2.77 & .88 & $*$ \\
3 & .13 & .10 & .11 & .00 & .00 & B \\
12 & .46 & .14 & .35 & 2.17 & .82 & $\mathrm{~J}$ \\
6 & .35 & .10 & .31 & .72 & .34 & $\mathrm{~K}$ \\
220 & .55 & .04 & .50 & 2.83 & .89 & $\mathrm{M}$ \\
10 & .47 & .18 & .59 & 2.66 & .88 & $\mathrm{U}$ \\
\hline
\end{tabular}

Explanation:

$\begin{array}{llll}\mathrm{B} & =\text { Bugis } & \mathrm{U} & =\text { Melayu } \\ \mathrm{J} & =\text { Jawa } & \mathrm{M} & =\text { Minang } \\ \mathrm{K} & =\text { Kerinci } & & \end{array}$

Dari seluruh etnis yang mengisi instrumen penerimaan diri, etnis bugis yang memiliki nilai mean measure paling rendah dibandingkan etnis lainnya, karena jumlah siswa Bugis yang mengisi instrumen terlalu sedikit yaitu 3 siswa, sehingga rasch tidak dapat melakukan analisis reliability dan separation. Namun, etnis yang dominan mengisi instrumen adalah etnis Minang $(\mathrm{n}=220)$, didukung dengan nilai mean measure $(.55$ logit) dan model reliability (.89) lebih tinggi dibandingkan dengan etnis lainnya.

\begin{tabular}{|c|c|c|c|c|c|c|}
\hline Person & Mean & S.E. & Median & Model & Model & Code \\
\hline Count & Measure & Mean & & Separation & Reliability & \\
\hline 251 & .53 & .04 & .49 & 2.77 & .88 & * \\
\hline 166 & .56 & .05 & .52 & 2.84 & .89 & B \\
\hline 76 & .51 & .06 & .47 & 2.47 & .86 & $\mathrm{~K}$ \\
\hline 9 & .24 & .23 & -.12 & 3.26 & .91 & $\mathrm{P}$ \\
\hline \multicolumn{7}{|c|}{ Explanation: } \\
\hline $\mathrm{B}=1$ & Besar & & & & & \\
\hline$=1$ & Kecil/kabu & Cota & & & & \\
\hline $\mathrm{P} \quad=1$ & & & & & & \\
\hline
\end{tabular}

Tabel $6<$ Hasil Uji Deskriptif Penerimaan Diri Berdasarakan Asal Domisili>

Tabel 6 menunjukkan siswa yang paling dominan mengisi instrumen penerimaan diri dari daerah kota besar $(\mathrm{n}=166)$. Namun, yang memberikan respon terbaik bukan dari kota besar, melainkan dari daerah 
pedesaan, terlihat dari nilai reliability sebesar .91, artinya kualitas jawaban yang diberikan siswa dari desa lebih tinggi dibandingkan dengan daerah lainnya. Selanjutnya, disampaikan kondisi penerimaan diri berdasarkan interaksi di sosial media (jumlah akun dan pertemanan) melalui grafik berikut.

\section{Kondisi Penerimaan diri Berdasarkan Interaksi di Sosial Media: Differential Item Functional}

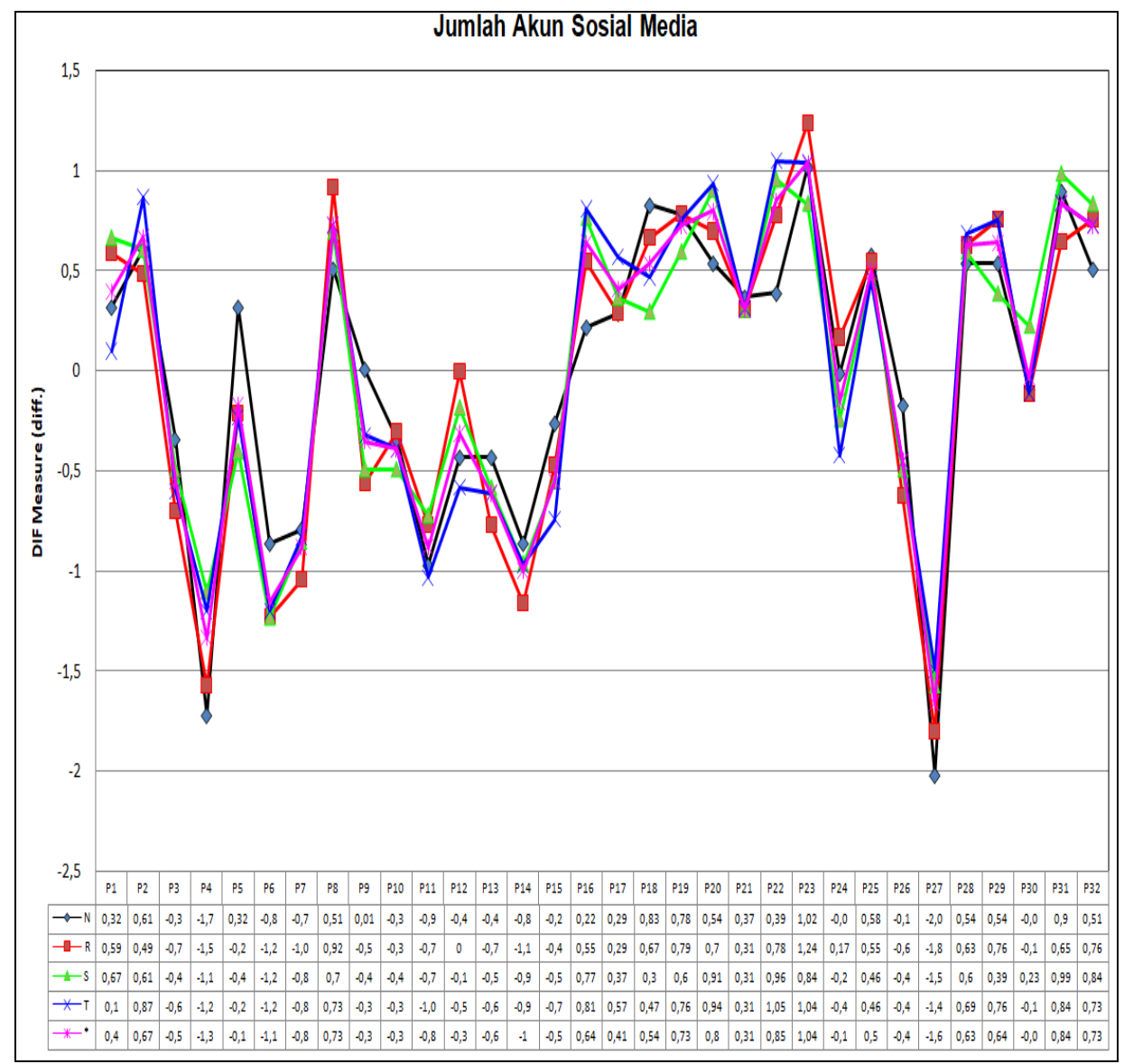

Gambar $2<$ Kondisi Penerimaan Diri Berdasarkan Jumlah Akun Sosial Media>

Pada gambar 2 menunjukkan warna merah dengan kode $\mathrm{R}=2$ akun membentuk grafik paling tinggi dibandingkan warna/kode lain. Namun, yang cenderung tinggi adalah kode $\mathrm{N}=1$ akun social media, artinya siswa dengan akun sosial media paling sedikit memiliki penerimaan diri tertinggi, terlihat dari kemampuan siswa menyetujui instrument. Jumlah akun di sosial media berkorelasi negatif terhadap penerimaan diri siswa Sekolah Menengah Atas (SMA) di Indonesia, semakin banyak siswa mengakses informasi baru terkait perilaku disosial media, maka siswa akan kurang menerima dirinya. Individu sering berbagi pesan pribadi dengan pengguna lain, melihat dan membaca berita, dan mengunggah foto/video atau berbagi status yang menggambarkan kondisi mereka (Moningka \& Eminiar, 2020). Kondisi ini didukung oleh (Piechowski, 2006) menyatakan bahwa remaja saat ini dipupuk dalam lingkungan sosial dan belajar yang telah banyak dipengaruhi oleh perkembangan teknologi, seperti: kurangnya kesadaran perasaan empati, dan penilaian diri, sehingga konsep diri remaja lebih terkena distorsi daripada di masa lalu. Individu ingin menjadi tipe orang yang dirasa menjadi diri yang ideal, karena dengan diri ideal/sempurna dapat membantu diri dalam mengembangkan potensinya dan mencapai aktualisasi diri (Rogers, 1951).

Pada gambar 3 menunjukkan warna hitam dengan kode $1=<200$ pertemanan membentuk grafik paling tinggi dibandingkan warna/kode lain. Selaras dengan grafik yang cenderung tinggi adalah warna hitam dengan kode $1=<200$ pertemanan sosial media, artinya siswa dengan pertemanan di sosial media paling sedikit memiliki penerimaan diri tertinggi dibandingkan dengan siswa yang memiliki pertemanan banyak. Dari hasil gambar 2 dan 3 menunjukkan hubungan yang erat, di mana jumlah akun social media dan jumlah pertemanan berkorelasi positif, semakin banyak akun sosial media maka juga semakin banyak jumlah pertemanan. Media sosial memungkinkan individu lebih mudah membuat perbandingan dan lebih sering mengakses media sosial dimanapun dan kapanpun (Moningka \& Eminiar, 2020). 


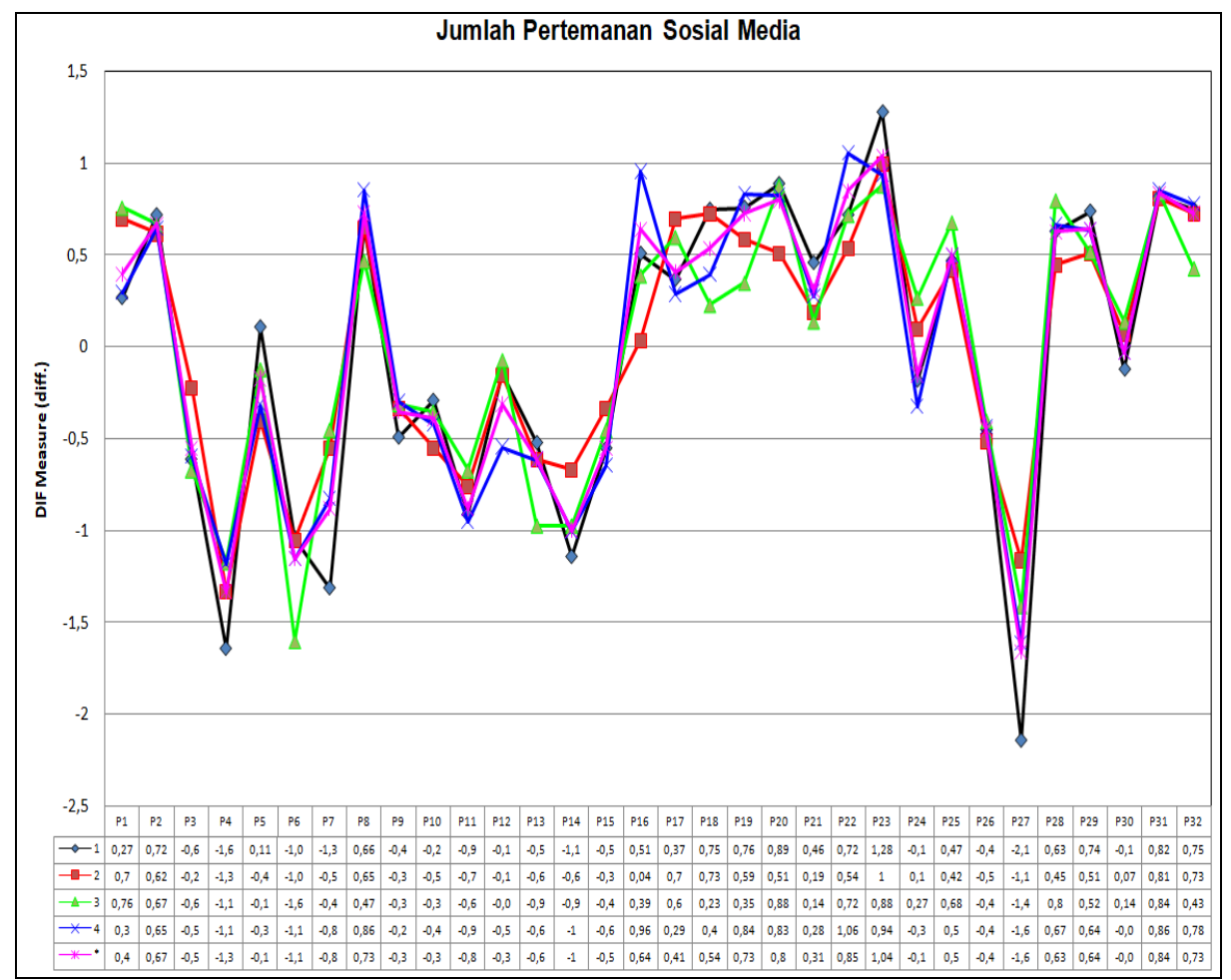

Gambar 3 <Kondisi Penerimaan Diri Berdasarkan Jumlah Pertemanan Sosial Media>

Hal ini didukung oleh (Wang, Moon, Kwon, Evans, \& Stefanone, 2010) mengungkapkan tampilan foto profil seseorang di FB berpengaruh signifikan terhadap kemauan untuk menjalin pertemanan dengan pemilik profil, karena dengan tampilan foto profil yang menarik dapat membuat daya tarik fisik, sehingga digunakan sebagai isyarat visual ketika memilih siapa yang akan ditemaninya. Selain itu, (Sagioglou \& Greitemeyer, 2014) menyatakan bahwa media sosial memicu kecemburuan, dan dapat menurunkan mood positif. Individu memiliki kesempatan untuk melakukan perbandingan sosial dengan menggunakan informasi yang ditampilkan oleh pengguna lain di sosial media (Vogel, Rose, Roberts, \& Eckles, 2014). Kontrakdiksi dengan penelitian lain yang menyatakan bahwa kecenderungan individu menggunakan media sosial untuk berbagi aktivitas yang mencerminkan bagian kehidupan yang paling menyenangkan, dengan harapan mendapat tanggapan positif dari pengguna lain (Kim \& Lee, 2011). Mereka menunjukkan citra diri yang positif untuk membuat orang lain terkesan. Perilaku ini dapat dijadikan sebagai penyemangat karena adanya konten yang menggembirakan (Triastuti, Adrianto, \& Nurul, 2017).

Selain itu, media sosial memberikan ruang bagi seseorang untuk mengemukakan pendapat serta menyuarakan pikirannya, yang sebelumnya mungkin tidak pernah bisa diungkapkan karena keterbatasan wadah dalam berpendapat serta sebagai ruang ekspresi baru bagi masyarakat dunia (Marwan, 2016). Menunjukkan perhatian kepada teman yang bersedih merupakan bentuk self esteem yang dapat ditampilkan secara langsung maupun melalui perantara media. Social comparison dapat membantu proses interaksi antara individu dalam mengekspresikan kepeduliannya. Sebagai makhluk sosial, individu dihadapkan pada berbagai kondisi langsung disekitarnya yang diharapkan individu tersebut menampilkan self esteem. Apabila individu fokus kepada dunia virtual dalam mengekspresikan kepedulian, dikhawatirkan porsi untuk menampilkan self esteem secara langsung berkurang. Social comparison dapat mempengaruhi self esteem. Oleh karena itu, dalam social comparison perlu dipahami sifatnya membantu memudahkan, sehingga tidak semua hal dilakukan dengan gadget dapat tercapai dengan baik

Untuk itu perlunya implikasi bimbingan dan konseling untuk meningkatkan penerimaan diri (Negovan et al., 2011), adapun cara untuk meningkatkannya melalui pelatihan pengenalan diri dengan menggunakan petak johari (Handayani, Ratnawati, \& Helmi, 2015). Selain itu, dengan konseling realita untuk mengubah konsep diri yang negatif menjadi konsep diri positif, dengan pengubahan tingkah laku yang lebih bertanggung jawab, merencanakan dan melakukan tindakan tindakan tersebut (Putri, 2018). Demikian pula dengan rencana program konseling sekolah yang dikemukakan oleh (Negovan et al., 2011) mencakup wawasan yang mendukung remaja untuk mengembangkan struktur diri yang sehat, untuk mengurangi ketidaksesuaian diri dan untuk meningkatkan penerimaan diri tanpa mengubah peran diri ideal mereka dalam pengembangan diri mereka. 


\section{Kesimpulan}

Hasil temuan menunjukkan $18.3 \%$ berada pada kondisi penerimaan diri tinggi, $36.6 \%$ berada pada kondisi penerimaan diri sedang, dan $45.4 \%$ berada pada kondisi penerimaan diri rendah. Selain itu, siswa laki-laki (.58 logit) lebih tinggi penerimaan dirinya dibandingkan dengan perempuan (.51 logit). Dan siswa dari desa lebih tinggi penerimaan dirinya dibandingkan dengan siswa kota besar dan kota kecil/kabupaten. Lebih lanjut, hasil menunjukkan hubungan yang erat antara jumlah akun sosial media dan jumlah pertemanan, di mana jumlah akun sosial media dan jumlah pertemanan berkorelasi positif, semakin banyak akun sosial media maka juga semakin banyak jumlah pertemanan. Berdasarkan hasil temuan perlunya intervensi dari konselor untuk meningkatkan penerimaan diri dengan konseling realita untuk mengubah konsep diri yang negatif menjadi konsep diri positif, dan pelatihan pengenalan diri dengan menggunakan petak johari untuk mengenal diri pribadi. Hasil penelitian ini mempertimbangkan batasan tertentu yang harus diingat, sampel penelitian tidak mewakili semua remaja Indonesia. Temuan studi perlu direplikasi pada sampel siswa Sekolah Menengah Pertama dan Menengah Atas yang lebih representatif dan luas.

\section{Referensi}

Adiansah, W., Setiawan, E., Kodaruddin, W. N., \& Wibowo, H. (2019). Person in Environment Remaja Pada Era Revolusi Industri 4.0. Focus: Jurnal Pekerjaan Sosial, 2(1), 47-60.

Art, G. Y. (2016). Mobile Phone: Sejarah, Tuntutan Kebutuhan Komunikasi, Hingga Prestise. Alhadharah: Jurnal Ilmu Dakwah, 15(30), 1-18.

Bond, T. G., \& Fox, C. M. (2015). Applying the Rasch Model, Fundamentals Measurement in the Human Science (3rd edition). New York: Routledge.

Boone, W. J., Stever, J. R., \& Yale, M. S. (2014). Rasch Analysis in the Human Science. Dordrech: Springer.

Ceyhan, A. A., \& Ceyhan, E. (2010). Investigation of university students' self-acceptance and learned resourcefulness: a longitudinal study. Higher Education, 61(6), 649-661.

Handayani, M. M., Ratnawati, S., \& Helmi, A. F. (2015). Efektifitas pelatihan pengenalan diri terhadap peningkatan penerimaan diri dan harga diri. Jurnal Psikologi, 25(2), 47-55.

Hurlock, E. B. (2011). Psikologi Perkembangan: Suatu pendekatan sepanjang rentang kehidupan. Jakarta: Erlangga.

Ilma, V. A., \& Muslimin, Z. I. (2020). Self-Acceptance from Aqidah and Gender Perspectives. In Annual International Conference on Social Sciences and Humanities (AICOSH 2020), 196-199.

Kim, J., \& Lee, J. R. (2011). Facebook paths to happiness: Effects of the number Facebook friends and selfpresentation on subjective wellbeing. Cyberpsychology, Behavior, and Social Networking, 14(6), 359364.

Linacre, J. M. (2011). A User's Guide to WINSTEPS Ministeps Rasch-Model Computer Programs. https://doi.org/ISBN 0-941938-03-4

Marwan, M. R. (2016). Analisis Penyebaran Berita Hoax di Indonesia. Jurusan Ilmu Komunikasi, Fakultas Ilmu Komunikasi Universitas Gunadarma.

Maryam, S., \& Ifdil, I. (2019). Relationship between body image and self-acceptance of female students. Jurnal Aplikasi IPTEK Indonesia, 3(3), 129-136.

Moningka, C., \& Eminiar, P. R. (2020). The Effect of Self-Comparison in Social Media on Self Esteem. In 3rd International Conference on Intervention and Applied Psychology (ICIAP 2019) and the 4th Universitas Indonesia Psychology Symposium for Undergraduate Research (UIPSUR 2019), 383-389.

Nadkarni, A., \& Hofmann, S. G. (2012). Why do people use Facebook? Personality and Individual Differences, 52(3), 243-249.

Negovan, V., Bagana, E., \& Dinca, S. (2011). Gender, age and academic standards of school differences in adolescents' self acceptance. Procedia-Social and Behavioral Sciences, 12, 40-48.

Ogden, J. E., \& Evans, C. (1996). The problem of weighing: effects on body image, self esteem and mood. International Journal of Obesity, 20, 272-277.

Piechowski, M. (2006). Mellow out," they say. If I only could: Intensities and sensitivities of the young and bright. Madison, W: Yunasa Books.

Putri, R. K. (2018). Meningkatkan self-acceptance (penerimaan diri) dengan Konseling Realita berbasis Budaya Jawa. Prosiding Seminar Nasional Bimbingan Dan Konseling, 2(1), 118-128.

Rogers, C. . (1951). Client-centered therapy: Its current practices, implications, and theory. Boston: Houghton Mifflin.

Sagioglou, C., \& Greitemeyer, T. (2014). Facebook's emotional consequences: Why facebook causes a decrease in mood and why people still using it. Computer in Human Behavior, 35, 359-363.

Schwab, K. (2016). The Fourth Industrial Revolution. World Economic Forum. 
Simanjuntak, D. F. (2013). Gambaran penerimaan diri dan manfaat pendidikan psikologi pada mahasiswa psikologi jenjang sarjana. Universitas Indonesia.

Suprapto, M. H., Sari, M. P., \& Nurcahyo, F. A. (2015). Differences in Men's Body Dissatisfaction Based on the Type of Exercise Motivation. ANIMA Indonesian Psychological Journal, 31(1), 22-29.

Syahputra, Y., \& Erwinda, L. (2020). Perbedaan Nomophobia mahasiswa; analisis Rasch. JPPI (Jurnal Penelitian Pendidikan Indonesia), 6(2), 69-76. https://doi.org/https://doi.org/10.29210/02020616

Triastuti, E., Adrianto, D., \& Nurul, A. (2017). Kajian Dampak Penggunaan Media Sosial bagi Anak dan Remaja. Depok: Pusat Kajian Komunikasi FISIP UI.

Vogel, E. A., Rose, J. P., Roberts, L. R., \& Eckles, K. (2014). Social comparison, social media, and selfesteem. Psychology of Popular Media Culture, 3(4), 206-222.

Wang, S. S., Moon, S.-I., Kwon, K. H., Evans, C. A., \& Stefanone, M. A. (2010). Face off: Implications of visual cues on initiating friendship on Facebook. Computers in Human Behavior, 26, 226-234.

Yahya, F. (2013). Hubungan penerimaan diri dan motivasi akademik intrinsik pada mahasiswa yang kuliah tidak pada jurusan yang diinginkan. Universitas Indonesia.

Yusuf, S. (2006). Psikologi Perkembangan Anak \& Remaja. Bandung: Remaja Rosdakarya.

ZAP Clinic. (2018). ZAP beauty index," 2018, ZAP Clinic. Retrieved from zapclinic.com/zap-beauty-indexdownload website: zapclinic.com/zap-beauty-index-download 